\title{
Efficiency of Reductive Soil Disinfestation Affected by Soil Water Content and Organic Amendment Rate
}

\author{
Rui Zhu ${ }^{1,2}$, Xinqi Huang ${ }^{3,4,5,6}$, Jinbo Zhang ${ }^{3,4,5,6}$, Zucong Cai ${ }^{3,4,5,6}$, Xun Li ${ }^{1,2,6}$ and Teng Wen $^{3,4,5,6, *}$ \\ 1 State Key Laboratory of Soil and Sustainable Agriculture, Institute of Soil Science, \\ Chinese Academy of Sciences, Nanjing 210008, China; zhurui@issas.ac.cn (R.Z.); xli@issas.ac.cn (X.L.) \\ 2 University of Chinese Academy of Sciences, Beijing 100049, China \\ 3 School of Geography, Nanjing Normal University, Nanjing 210023, China; xqhuang@njnu.edu.cn (X.H.); \\ zhangjinbo@njnu.edu.cn (J.Z.); zccai@njnu.edu.cn (Z.C.) \\ 4 Jiangsu Engineering Research Center for Soil Utilization \& Sustainable Agriculture, \\ Nanjing Normal University, Nanjing 210023, China \\ 5 Jiangsu Center for Collaborative Innovation in Geographical Information Resource Development \\ and Application, Nanjing 210023, China \\ 6 Zhongke Clean Soil (Guangzhou) Technology Service Co., Ltd., Guangzhou 510000, China \\ * Correspondence: wenteng@njnu.edu.cn
}

check for updates

Citation: Zhu, R.; Huang, X.; Zhang, J.; Cai, Z.; Li, X.; Wen, T. Efficiency of Reductive Soil Disinfestation Affected by Soil Water Content and Organic Amendment Rate. Horticulturae 2021, 7,559. https://doi.org/10.3390/ horticulturae7120559

Academic Editor: Giovanni Bubici

Received: 26 October 2021

Accepted: 6 December 2021

Published: 7 December 2021

Publisher's Note: MDPI stays neutral with regard to jurisdictional claims in published maps and institutional affiliations.

Copyright: (C) 2021 by the authors Licensee MDPI, Basel, Switzerland. This article is an open access article distributed under the terms and conditions of the Creative Commons Attribution (CC BY) license (https:// creativecommons.org/licenses/by/ $4.0 /)$.

\begin{abstract}
Reductive Soil Disinfestation (RSD) is a good method which can restore degraded greenhouse soil and effectively inactivate soil-borne pathogens. However, the approach needs to be optimized in order to facilitate its practical application in various regions. In the present work, we investigated the effect of soil water content $(60 \%$ water holding capacity (WHC), $100 \%$ WHC and continuous flooding) and maize straw application rates $\left(0,5,10\right.$, and $20 \mathrm{~g} \mathrm{~kg}^{-1}$ soil) on the improvement of soil properties and suppression of soil-borne pathogens (Fusarium oxysporum, Pythium and Phytophthora). The results showed that increasing the soil water content and maize straw application rate accelerated the removal of excess sulfate and nitrate in the soil and elevated the soil $\mathrm{pH}$. Elevating the water content and maize straw application rate also produced much more organic acids, which could strongly inhibit soil-borne pathogens. Soil properties were improved significantly after RSD treatment with a maize straw amendment rate of more than $5 \mathrm{~g} \mathrm{~kg}^{-1}$, regardless of the water content. However, RSD treatments with $60 \%$ WHC could not effectively inactivate soil-borne pathogens and even stimulated their growth by increasing the maize application rate. RSD treatments of both $100 \%$ WHC and continuous flooding could inactivate soil-borne pathogens and increase the pathogens mortality indicated by cultural cells relatively effectively. The inhibited pathogens were significantly increased with the increasing maize application rate from $5 \mathrm{~g} \mathrm{~kg}^{-1}$ to $10 \mathrm{~g} \mathrm{~kg}^{-1}$, but were not further increased from $10 \mathrm{~g} \mathrm{~kg}^{-1}$ to $20 \mathrm{~g} \mathrm{~kg}^{-1}$. A further increased mortality of F. oxysporum, indicated by gene copies, was also observed when the soil water content and maize straw application rate were increased. Therefore, RSD treatment with $60 \%$ WHC could improve soil properties significantly, whereas irrigation with $100 \%$ WHC or continuous flooding was a necessity for effective soil-borne pathogens suppression. Holding 100\% WHC and applicating maize straw at $10 \mathrm{~g} \mathrm{~kg}^{-1}$ soil were optimum conditions for RSD field operation to restore degraded greenhouse soil.
\end{abstract}

Keywords: application rate; nitrate; organic acid; soil-borne pathogens; soil $\mathrm{pH}$; sulfate

\section{Introduction}

Greenhouse cultivation plays a very important role in vegetable production all over the world. The health status of greenhouse soil directly influences the yield and the quality of the products from greenhouse cultivation [1]. Yet, driven by the economic benefits, farmers usually apply a large amount of chemical fertilizer for intensive vegetable production in greenhouses in China [2,3]. As a result, acidification and salinization widely occur in greenhouse soil, which not only greatly deteriorates the physical and chemical 
properties of soil, but also induces serious soil-borne disease [3,4]. This problem has become the bottleneck for sustainable development of greenhouse cultivation all over the world, especially in China $[5,6]$.

Reductive soil disinfestation (RSD), also known as biological soil disinfestation (BSD) or anaerobic soil disinfestation (ASD), is an emerging environmentally friendly method and effective alternative to chemical fumigations [7]. This method was first proposed by Shinmura [8] and Blok [9], and was characterized by applying labile carbon to develop microbial-driven anaerobic soil conditions in moist or flooded soil covered with polyethylene mulch [7]. It was proven to control a wide range of soil-borne pathogens and nematodes, as well as improve soil properties and microbial environment $[7,10,11]$.

RSD needs to apply a large amount of organic material to the soil. Various kinds of organic materials have been used for RSD treatment, including rye-grass, straw stalk, wheat bran, syrup, ethanol, animal waste, and so on [12-16]. However, organic material is not always easily accessible; sometimes this entails expensive purchase and delivery costs. In China, crop residues, such as crop straws, which are usually recognized as agricultural production wastes, can be easily obtained in most areas. Their management and recycling were also long-standing problems for sustainable agriculture. Open-field burning is the most common approach to treat crop residues, but this undoubtedly leads to heavy air pollution. For this reason, applying crop straw as an organic amended material not only helps to recycle waste straw, but also reduces the costs of RSD treatment. Previous studies discovered that maize straw performs well as an organic, amended material for RSD, in which application of $5 \mathrm{~g}$ maize straw $\mathrm{kg}^{-1}$ in saturated soil $(100 \%$ water holding capacity, WHC) could inactivate more than $90 \%$ soil-borne pathogens [17].

RSD also needs large amount of water, but it is not appropriate for flooding in all areas. Soil water holding capacity is affected by soil texture and topography greatly; soil abundant in organic matters can hold more water than sandy soil [18], and it is difficult to implement flooding in hilly areas and uplands. Moreover, water resources are very precious; therefore, it is very necessary to develop a more efficient water-saving method for RSD. Previous studies showed that irrigating soil to $100 \%$ WHC and the simultaneous mulching with polyethylene films could create same highly anaerobic environments $[18,19]$ and effectively kill soil-borne pathogens with a maize straw application rate of $5 \mathrm{~g} \mathrm{~kg}^{-1}$ soil, as in flooded soil [11]. However, in view of the cost and practicability, an optimum soil water content and amendment rate have not yet been proposed. Accordingly, the aim of this study was to explore the effects of water content and organic amendment rates of RSD treatment on the suppression of soil-borne pathogens and improvement of soil properties, and then to propose an optimum soil water content and maize straw application rate for RSD field operation.

\section{Materials and Methods}

\subsection{Materials}

The soil for the present laboratory experiment was collected from a greenhouse in Baguazhou, Nanjing, China (118.81 E, $32.19 \mathrm{~N})$. The soil was of a clay loamy texture and used as growing substrate of Artemisia selengensis for several years. Fusarium wilt disease perniciously spread among the field, and the soil was severely degraded in this area. All soil samples collected from this area were sieved through $2 \mathrm{~mm}$ sieve before experiment. The maize straw was collected as the organic material from Hongta county, Lilou towns, Bengbu, Anhui, China (117.44 E, 32.87 N). Before mixed into soil, the straw was air-dried, crushed and sieved through $2 \mathrm{~mm}$ sieve. The total organic carbon (TOC), total N (TN), easily oxidized carbon (EOC) and $\mathrm{C} / \mathrm{N}$ of the soil sample and maize straw are shown in Table 1. 
Table 1. Total N, total C, easily oxidized carbon (EOC) content and $\mathrm{C} / \mathrm{N}$ ratio of maize straw and the soil used in this study.

\begin{tabular}{ccccc}
\hline Sample & Total C $\left(\mathrm{g} \mathrm{kg}^{-\mathbf{1}}\right)$ & Total $\mathbf{~}\left(\mathrm{g} \mathrm{kg}^{-\mathbf{1}}\right)$ & EOC $\left(\mathbf{m g ~ k g}^{-\mathbf{1}}\right)$ & $\mathbf{C} / \mathbf{N}$ \\
\hline Maize straw & 505.1 & 10.64 & 1.75 & 47.47 \\
Soil & 23.65 & 2.68 & 0.05 & 8.82 \\
\hline
\end{tabular}

\subsection{Experiment Design}

Prepared soil samples ( $250 \mathrm{~g}$ soil on air-dry basis), which were thoroughly mixed with maize straw at designed rates, were placed into self-closure bags. The PE bags were $15 \mathrm{~cm}$ long, $9 \mathrm{~cm}$ wide, and $0.1 \mathrm{~mm}$ thick. The soil water content was set at $60 \% \mathrm{WHC}, 100 \%$ WHC, and continuous flooding, respectively. The straw amendment rate was set at $0,5,10$, and $20 \mathrm{~g} \mathrm{~kg}^{-1}$ soil, respectively. Soil samples subjected only to water content modification were referred as CK treatments, while those subjected to both water and maize straw modifications were designed as RSD treatments. Thus, there were 12 treatments which were listed in Table 2. Each treatment set three replicates and all closed bags were incubated randomly at $30{ }^{\circ} \mathrm{C}$. Previous studies showed that organic acids were one of the key factors in the sterilization of RSD [20]. For measuring organic acids in the soil solution during the incubation, a soil solution (about $2 \mathrm{~mL}$ ) was collected by pre-embedded porous-cup soil solution sampler (DIK-8393; Daiki Rika Kogyo, Saitama, Japan) [21] on days 4, 8, 12, and 15 after incubation. The sampler was completely buried into the mixed soil in each bag for the nondestructive collection of soil solution samples through a syringe with a two-way valve, then by adding water to the objective soil water content [22]. At the end of 15 days of incubation, the physical and chemical properties of soil samples and the populations of Fusarium oxysporum spp., Pythium spp. and Phytophthora spp. in soil samples were determined.

Table 2. Treatments list.

\begin{tabular}{|c|c|}
\hline Number & Treatment \\
\hline 1 & CK-60\% WHC \\
\hline 2 & $60 \% \mathrm{WHC}+5 \mathrm{~g}$ maize straw $\mathrm{kg}^{-1}$ soil \\
\hline 3 & $60 \% \mathrm{WHC}+10 \mathrm{~g}$ maize straw $\mathrm{kg}^{-1}$ soil \\
\hline 4 & $60 \% \mathrm{WHC}+20 \mathrm{~g}$ maize straw $\mathrm{kg}^{-1}$ soil \\
\hline 5 & CK $-100 \%$ WHC \\
\hline 6 & $100 \% \mathrm{WHC}+5 \mathrm{~g}$ maize straw $\mathrm{kg}^{-1}$ soil \\
\hline 7 & $100 \% \mathrm{WHC}+10 \mathrm{~g}$ maize straw $\mathrm{kg}^{-1}$ soil \\
\hline 8 & $100 \% \mathrm{WHC}+20 \mathrm{~g}$ maize straw $\mathrm{kg}^{-1}$ soil \\
\hline 9 & $\mathrm{CK}$-continuous flooding \\
\hline 10 & Continuous flooding $+5 \mathrm{~g}$ maize straw $\mathrm{kg}^{-1}$ soil \\
\hline 11 & Continuous flooding $+10 \mathrm{~g}$ maize straw $\mathrm{kg}^{-1}$ soil \\
\hline 12 & Continuous flooding $+20 \mathrm{~g}$ maize straw $\mathrm{kg}^{-1}$ soil \\
\hline
\end{tabular}

\subsection{Soil Analyses}

Soil $\mathrm{pH}$ was measured in slurry (soil: water $=1: 2.5$ ) by a $\mathrm{pH}$ electrode (Mettler S220K, Greifensee, Switzerland) [23,24]. Nitrate and ammonium concentrations in soil were extracted by $2 \mathrm{~mol} \mathrm{~L}^{-1} \mathrm{KCl}$ solution (soil: water $=1: 5$ ) after $250 \mathrm{rpm}$ shaking for $1 \mathrm{~h}$, and then measured by a continuous-flow analyzer (Skalar San++, Breda, Holland) [17]. Soil EC was measured in filtrate (soil: water $=1: 5$ ) by a conductivity meter (KangYi Corp., Shanghai, China) after $180 \mathrm{rpm}$ shaking for $20 \mathrm{~min}$ [23]. $\mathrm{SO}_{4}{ }^{2-}$ concentration in the soil was measured in filtrate (soil: water $=1: 5$ ) by ion chromatography (Thermo Dionex ICS 1100, Waltham, MA, USA) [25]. Soil TOC was measured by wet digestion [26]. Soil TN was measured by Macro Kjeldahl method [27]. Soil EOC was measured by the potassium permanganate oxidation method [28]. The maximum water holding capacity of soil was measured as follows: First, the soil was thoroughly mixed with the corresponding amount 
of maize straw. Second, the soil was thoroughly flooded in a funnel equipped with filter paper for $2 \mathrm{~h}$. Then, free water was leached out for $6-8 \mathrm{~h}$. Until this point, the soil water content was defined as $100 \%$ WHC. The amended water holding capacity of soil without maize straw was calculated at the same time. The soil water content was determined by drying the soil at $105^{\circ} \mathrm{C}$ to a constant mass.

Organic acids produced during RSD in the soil solution were measured by HPLC (Agilent 1260, Santa Clara, CA, USA) with a modification according to the literature [29]. The column was XDB-C18 $(4.6 \times 250 \mathrm{~mm}$, Agilen, USA), and the mobile phase was consisted of different gradient dilution of $2.5 \mathrm{mM} \mathrm{H}_{2} \mathrm{SO}_{4}$ (A) and methanol (B) at a flow rate of $1 \mathrm{~mL} \mathrm{~min}{ }^{-1}$. The composition of gradients was set as follows: $0-5 \mathrm{~min}, 95 \%$ A plus $5 \% \mathrm{~B} ; 5-13 \mathrm{~min}, 95 \%$ A plus $5 \% \mathrm{~B} ; 13-53 \mathrm{~min}, 85 \%$ A plus $15 \% \mathrm{~B}$; and $53 \mathrm{~min}$ stop, $85 \%$ A plus $15 \%$ B. The wavelength of UV detector was set at $210 \mathrm{~nm}$. The quantification of organic acid was calculated by comparing the time of the peak appearance and the peak area with the standard samples.

\subsection{The Population of the Main Soil-Borne Pathogens: Fusarium oxysporum spp., Pythium spp. and Phytophthora spp.}

Plate count method was used to count the cultural cells in different soil samples. Ten-times-step dilution was applied when performing the dilution plating procedure. $\mathrm{K} 2$ medium [30] was used for the growth of Fusarium oxysporum spp. $\left(\mathrm{K}_{2} \mathrm{HPO}_{4} 1 \mathrm{~g}\right.$, $\mathrm{MgSO}_{4} \cdot 7 \mathrm{H}_{2} \mathrm{O} 0.5 \mathrm{~g}$, $\mathrm{KCl} 0.5 \mathrm{~g}$, Fe-Na-EDTA $0.01 \mathrm{~g}$, L-Asparagine $2 \mathrm{~g}$, D-galactose $2 \mathrm{~g}$, agar $24 \mathrm{~g}$, distilled water $1000 \mathrm{~mL}$. PCNB $1 \mathrm{~g}, \mathrm{Na}_{2} \mathrm{~B}_{4} \mathrm{O}_{7} \cdot 10 \mathrm{H}_{2} \mathrm{O} 0.5 \mathrm{~g}$, Streptomycin $0.12 \mathrm{~g}$, $10 \% \mathrm{H}_{3} \mathrm{PO}_{4}$ for adjusting $\mathrm{pH}$ to 3.8-4.0 after sterilization). Maize meal agar was used for the growth of Pythium spp. (maize meal agar 20 g, distilled water $1000 \mathrm{~mL}$; Pimarincin $50 \mathrm{mg}$ and Ampicillin $250 \mathrm{mg}$ after sterilization). Oatmeal agar was used for the growth of Phytophthora spp. First, by adding $20 \mathrm{~g}$ of oatmeal to $900 \mathrm{~mL}$ of water, and then boiling the water lightly for $45 \mathrm{~min}$, filtering the solution, adding distilled water and $24 \mathrm{~g}$ agar to $1000 \mathrm{~mL}$. Ampicillin (200 mg) and rifampicin $(20 \mathrm{mg})$ was amended after sterilization.

\subsection{Extraction of Soil DNA and Quantification of Fusarium oxysporum}

Soil DNA was extracted through the Power Soil TM DNA Isolation Kit (MOBIO Laboratories Inc., Carlsbad, CA, USA) according to the kit instructions and [31]. Real-time PCR was performed on the CFX-96 thermocycler (Bio-Rad Laboratories Inc., Hercules, CA, USA). The $20 \mu \mathrm{L}$ reaction system was designed as follows: $2 \mu \mathrm{L}$ DNA template, $10 \mu \mathrm{L}$ SYBR GREEN premix EX Taq $(2 \times$, TaKaRa, Dalian, China), $6 \mu \mathrm{L}$ sterile deionized water, $1 \mu \mathrm{L}$ primer of $\mathrm{F}$ and $1 \mu \mathrm{L}$ primer of R (ITS1-F (F): 5'-CTTGGTCATTTAGAGGAAGTAA-3' [32] and AFP308 (R): $5^{\prime}$-CGAATTAACGCGAGTCCCAAC-3 $3^{\prime}\left(10 \mu \mathrm{mol} \mathrm{L}^{-1}\right)$ [33]). Reaction conditions were designed as follows: Pre-denaturation step at $95^{\circ} \mathrm{C}$ for 2 min followed by 40 cycles, including denaturation at $95^{\circ} \mathrm{C}$ for $10 \mathrm{~s}$, annealing at $58^{\circ} \mathrm{C}$ for $15 \mathrm{~s}$, extended at $75^{\circ} \mathrm{C}$ for $20 \mathrm{~s}$. Melt curve profiles were obtained at annealing step in each cycle.

\subsection{Statistical Analyses}

Differences among treatments were assessed with ANOVA analysis. LSD test and SNK test was applied in SPSS 22.0 (SPSS Inc., Chicago, IL, USA) when ANOVA analysis revealed significant differences at $p<0.05$. Origin 2016 was used to create diagrams.

\section{Results}

\subsection{Soil $p H$ and $E C$}

The soil pH in all RSD treatments was significantly increased at the end of treatments (Figure 1 and Table 3). The initial soil $\mathrm{pH}$ was 4.42. After the RSD treatments, soil $\mathrm{pH}$ was slightly increased in CK, and was further increased in RSD treatments. Among treatments with the same maize straw application rates, flooded soil and 100\% WHC soil always had higher $\mathrm{pH}$ values than $60 \%$ WHC soil. Adding more maize straw helped to achieve higher $\mathrm{pH}$ values in $100 \%$ WHC and flooded treatments. The highest $\mathrm{pH}$ (5.34) was observed in 
the flooded plus $20 \mathrm{~g}$ maize straw $\mathrm{kg}^{-1}$ soil treatment. In $60 \%$ WHC treatments, however, soil $\mathrm{pH}$ was not significantly increased with the increasing maize straw application rates from $5 \mathrm{~g} \mathrm{~kg}^{-1}$ to $20 \mathrm{~g} \mathrm{~kg}^{-1}$. Generally, soil EC had a decreased trend with increasing water content (Figure 1). However, the effects of the water content and straw amendment rate, and their interaction on soil EC, were not significant (Table 3).

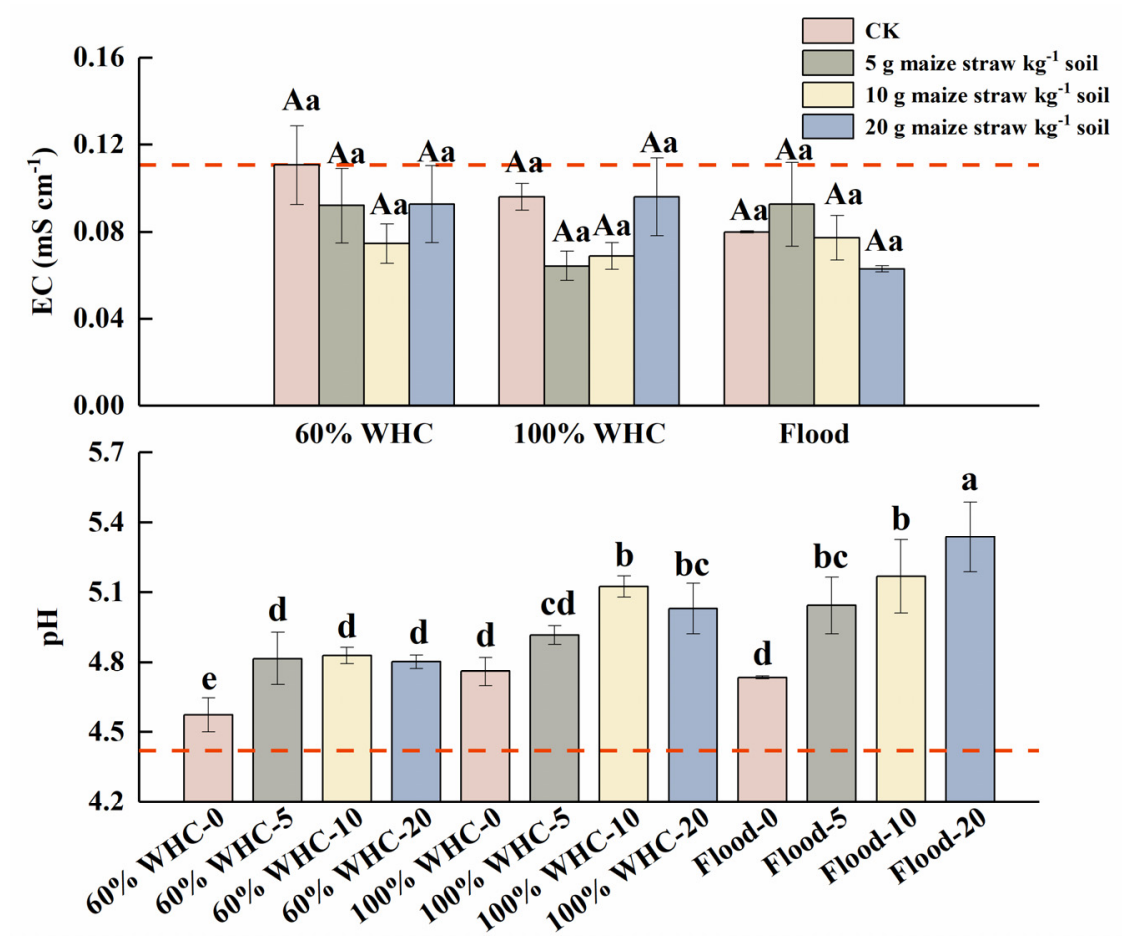

Figure 1. The effects of water content and maize amendment rate on soil EC and pH after RSD treatment. Error bars indicate standard deviations. Different uppercase letters in EC implicate the a significant difference among the same maize straw amended rate under different soil water contents, and lowercase letters within the same water content show significant differences among the various maize straw amended rates (SNK tests, $p<0.05$ ). Different lowercase letters show a significant difference among the various treatment of $\mathrm{pH}$ (SNK tests, $p<0.05)$. The dashed lines represent the initial value of the original soil.

Table 3. ANOVA analyses of the RSD effects of maize application rates and soil water contents on soil properties and populations of soil-borne pathogens.

\begin{tabular}{|c|c|c|c|c|c|c|c|c|}
\hline \multirow{2}{*}{ Variable } & \multicolumn{8}{|c|}{$p$-Value } \\
\hline & $\mathrm{pH}$ & EC & $\mathrm{SO}_{4}{ }^{2-}$ & $\mathrm{NH}_{4}{ }^{+}$ & $\mathrm{NO}_{3}{ }^{-}$ & F. oxysporum & Phytophthora & Pythium \\
\hline Straw rate $(\mathrm{S})$ & $<0.001$ & 0.239 & $<0.001$ & $<0.001$ & $<0.001$ & $<0.001$ & $<0.001$ & $<0.001$ \\
\hline $\begin{array}{c}\text { Water } \\
\text { content }(W)\end{array}$ & $<0.001$ & 0.266 & 0.365 & 0.002 & 0.132 & $<0.001$ & $<0.001$ & $<0.001$ \\
\hline $\mathrm{S} \times \mathrm{W}$ & 0.018 & 0.300 & 0.217 & 0.001 & 0.447 & $<0.001$ & $<0.001$ & $<0.001$ \\
\hline
\end{tabular}

\subsection{Soil $\mathrm{SO}_{4}{ }^{2-}, \mathrm{NH}_{4}{ }^{+}$and $\mathrm{NO}_{3}{ }^{-}$Contents}

Across all RSD treatments, $\mathrm{SO}_{4}{ }^{2-}$ and $\mathrm{NO}_{3}{ }^{-}$concentrations in soil were significantly decreased. On the contrary, soil $\mathrm{NH}_{4}{ }^{+}$concentration was increased distinctly in $60 \%$ WHC and 100\% WHC treatments when compared to CK (Figure 2). The effects of straw amendment on the $\mathrm{SO}_{4}{ }^{2-}, \mathrm{NO}_{3}{ }^{-}$and $\mathrm{NH}_{4}{ }^{+}$concentrations were significant, while the significant effect of water content only appeared in soil $\mathrm{NH}_{4}{ }^{+}$(Table 3). In CK treatments, soil $\mathrm{SO}_{4}{ }^{2-}$ and $\mathrm{NO}_{3}{ }^{-}$concentrations were effectively reduced $(p<0.05)$ and soil $\mathrm{NH}_{4}{ }^{+}$ increased when compared with their initial contents. This trend was much more clear after 
maize straw was amended. The contents of $\mathrm{NH}_{4}{ }^{+}$were double or triple their initial values, whereas $\mathrm{NO}_{3}{ }^{-}$was decreased from $3.36 \mathrm{mg} \mathrm{kg}^{-1}$ to almost zero $(p<0.001)$, and $\mathrm{SO}_{4}{ }^{2-}$ was reduced from $302 \mathrm{mg} \mathrm{kg}^{-1}$ to $79-128 \mathrm{mg} \mathrm{kg}^{-1}(p<0.001)$ in all RSD treatments. Although $\mathrm{SO}_{4}{ }^{2-}$ content shows the lowest in $100 \%$ WHC and flood-RSD treatment with the straw amendment rate of $20 \mathrm{~g} \mathrm{~kg}^{-1}$, no significant differences in $\mathrm{NO}_{3}{ }^{-}$and $\mathrm{NH}_{4}{ }^{+}$contents were observed among different straw amendment rates in the same soil water content treatments. On the other hand, despite the fact that $\mathrm{NO}_{3}{ }^{-}$and $\mathrm{SO}_{4}{ }^{2-}$ were significantly decreased in RSD treatment, there were no significant differences among different soil water content under the same straw amendment rate. RSD treatment with $60 \%$ WHC and $100 \%$ WHC showed the same efficiency in lifting soil $\mathrm{NH}_{4}{ }^{+}$content and removing soil $\mathrm{NO}_{3}{ }^{-}$content as the continuous flooding treatments.
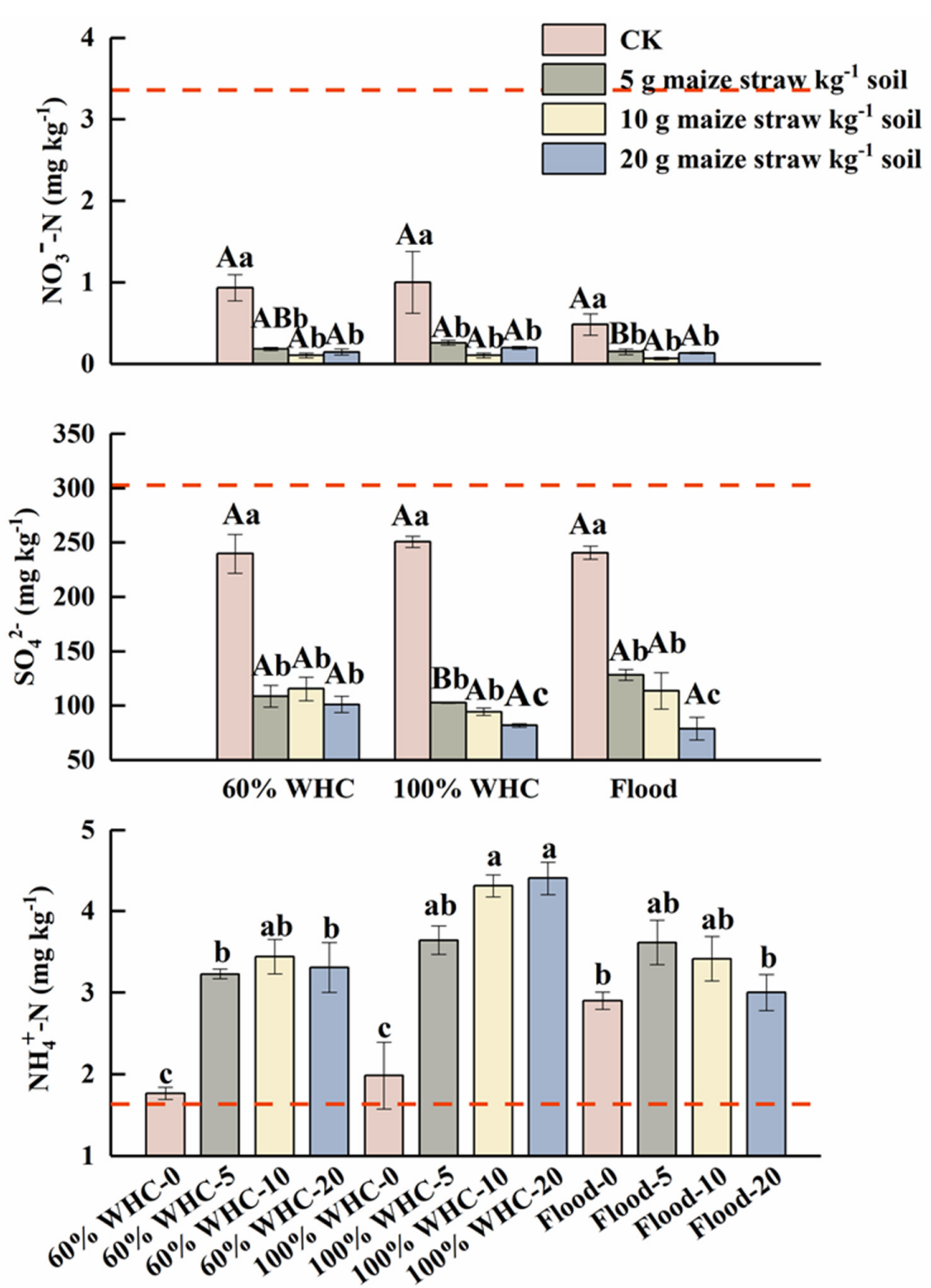

Figure 2. The contents of $\mathrm{NO}_{3}{ }^{-}, \mathrm{SO}_{4}{ }^{2-}$ and $\mathrm{NH}_{4}{ }^{+}$after $\mathrm{RSD}$ treatment. Error bars indicate standard deviations. Different uppercase letters implicate the significant difference among the same maize straw amended rate under the different soil water contents of $\mathrm{NO}_{3}{ }^{-}$and $\mathrm{SO}_{4}{ }^{2-}$, and lowercase letters within the same water content show a significant difference among the various maize straw amended rates (SNK tests, $p<0.05$ ). Different lowercase letters show a significant difference among the various treatments of $\mathrm{NH}_{4}{ }^{+}(\mathrm{SNK}$ tests, $p<0.05)$. The dashed lines represent the initial value of the original soil. 


\subsection{Dynamics of Organic Acids during the RSD Treatment}

A great quantity of organic acids, which were toxic to soil-borne pathogens [34], were produced in all RSD treatments, but none of them were detected in CKs (Figure 3). Acetic acid exhibited the highest concentration among the four detectable acids, followed by propionic acid and butyric acid, while isovaleric acid was the most minor acid and only showed low concentrations in the flooded RSD treatment amended with a high amount of maize straw. The elevating application rate of maize straw helped to produce more organic acids. The concentrations of acetic acid in RSD treatments with maize amendment rate of $20 \mathrm{~g} \mathrm{~kg}^{-1}$ were fivefold to tenfold compared to those with $5 \mathrm{~g} \mathrm{~kg}^{-1}$. Moreover, organic acids concentrations maintained high levels throughout the treating period in RSD applied with high amended rates of maize straw, but declined to almost zero after 15 days' incubation in those with low amended rates of maize straw.

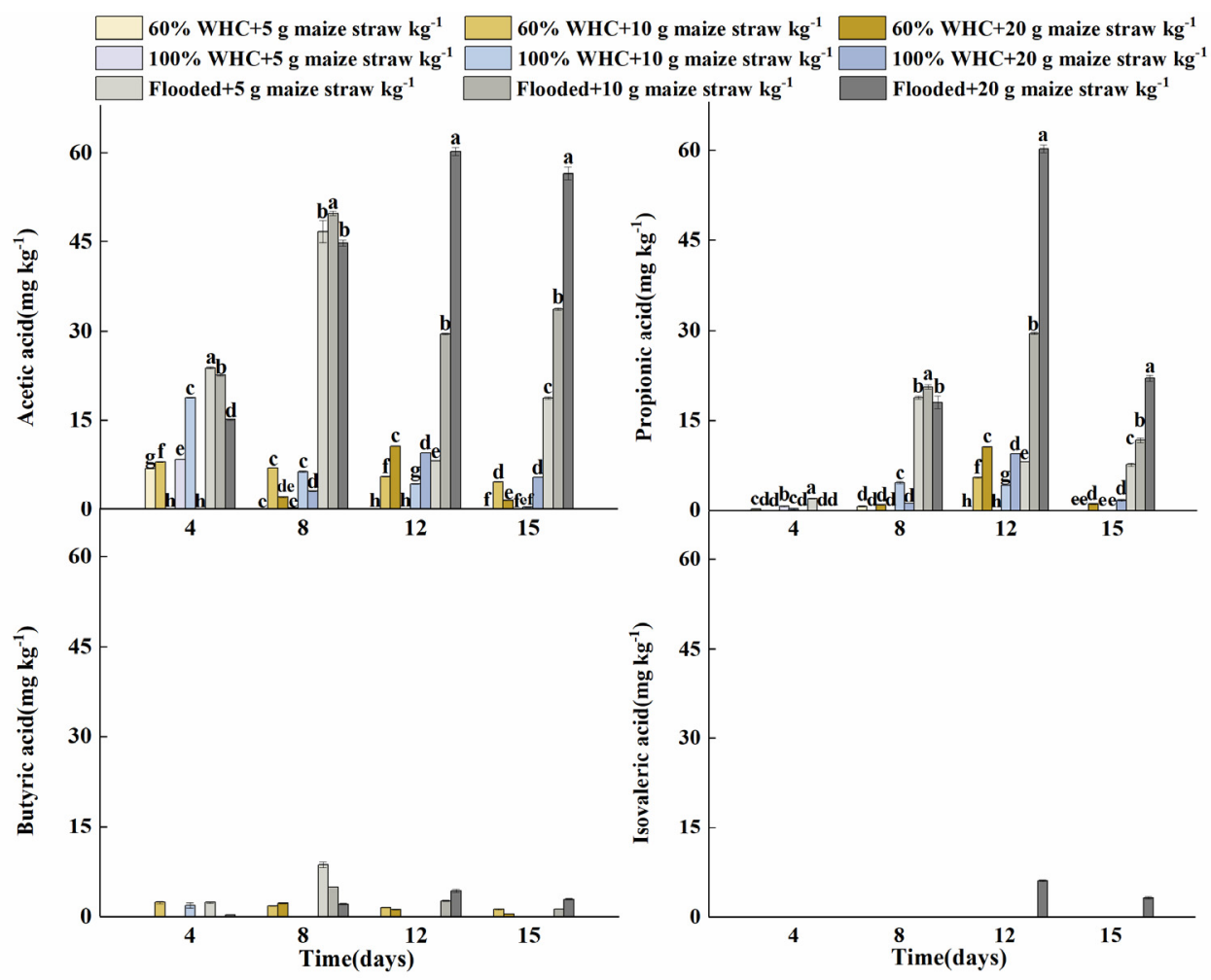

Figure 3. Dynamics of organic acids during the RSD treatments. Error bars indicate standard deviations. Different lowercase letters show significant differences among the various maize straw amended rates and soil water contents. $(p<0.05)$. CKs were not displayed in the figure because no organic acid was detected throughout the incubation period.

\subsection{Community of Soil-Borne Pathogens}

The populations of soil-borne pathogens (F. oxysporum spp., Phytophthora spp. and Phyrium spp.) were counted through selective cultural mediums. Compared with CK, in which the populations of pathogens were only slightly reduced or even increased from the initial values, RSD treatments by applying maize straw into $100 \%$ WHC or flooded soil dramatically killed pathogens $(p<0.001$, Figure 4$)$. Both water content and straw amendment rate and their interaction significantly affected the populations of studied soil-borne pathogens (Table 3). However, the water content in the soil has a smaller effect on the content of pathogenic microorganisms than the addition of straw to $100 \%$ WHC and flooded soil. The highest mortalities of all three pathogens were found in treatments applying with maize straw at $20 \mathrm{~g} \mathrm{~kg}^{-1}$, which inactivated more than $96 \%$ of pathogens (F. oxysporum spp., Phytophthora spp. and Phyrium spp.) in both flooded and $100 \%$ WHC soil. Applying maize straw at $5 \mathrm{~g} \mathrm{~kg}^{-1}$ into flooded soils also effectively reduced up to 
90\% of F. oxysporum spp. and Pythium, but no statistically significant differences were observed between this treatment and CK in the 100\% WHC condition. Increasing the straw applying rate to 10 and $20 \mathrm{~g} \mathrm{~kg}^{-1}$ in both flooded and $100 \%$ WHC soil significantly decreased the populations of studied soil-borne pathogens by more than $95 \%$, and the differences between the straw applying rate of 10 and $20 \mathrm{~g} \mathrm{~kg}^{-1}$ were not significant. In $60 \%$ WHC soil; however, the highest pathogens mortality was less than $60 \%$ even when the highest rate of maize straw $\left(20 \mathrm{~g} \mathrm{~kg}^{-1}\right)$ was applied. Instead, it seemed that the more maize straw that was used, the less the pathogens were suppressed. In the treatments of $60 \%$ WHC $+20 \mathrm{~g}$ maize straw $\mathrm{kg}^{-1}$ soil, the populations of three pathogens increased twofold, fivefold and onefold, respectively, compared with the CK $(p<0.05)$.
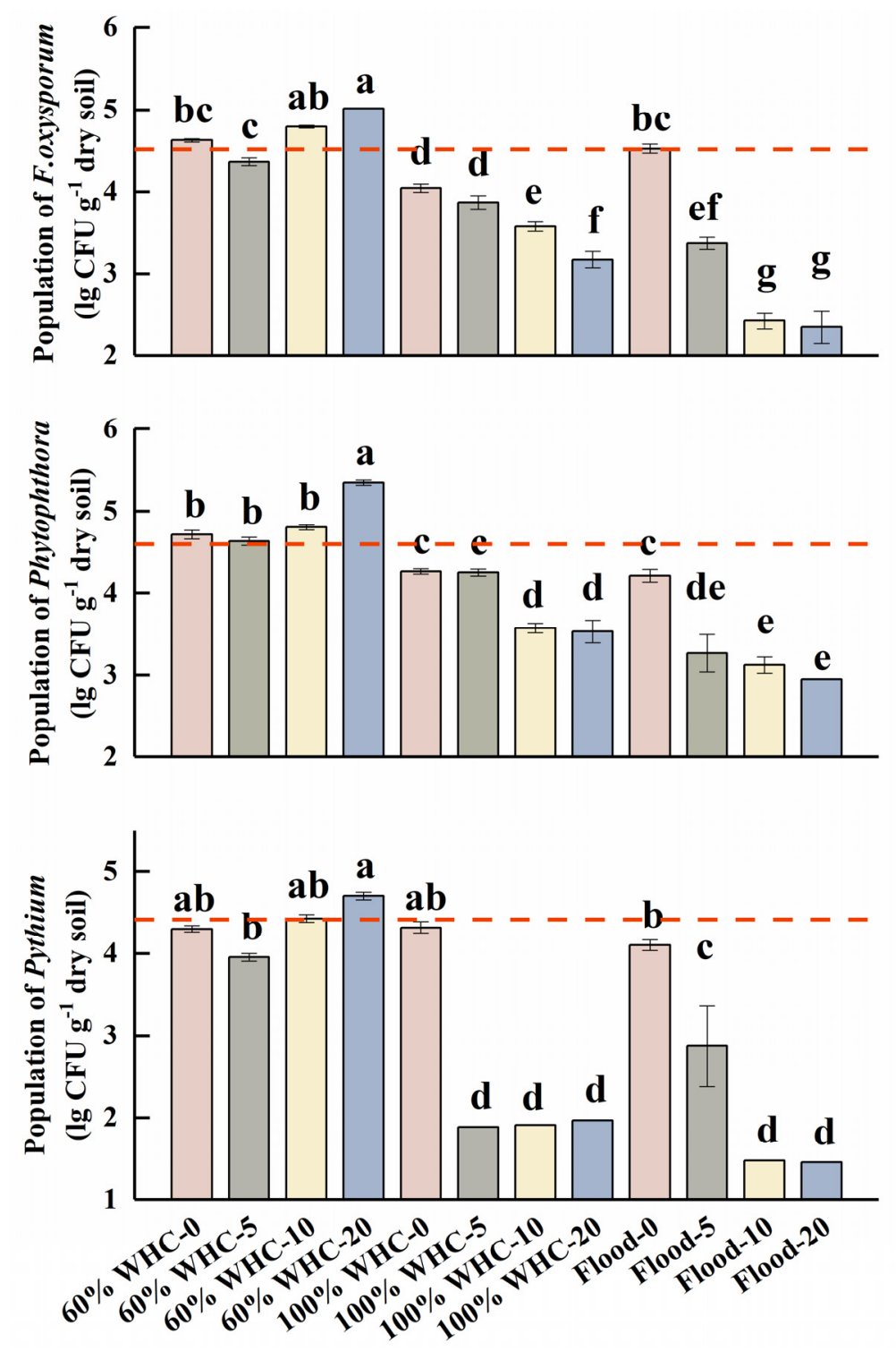

Figure 4. The populations of F. oxysporum, Phytophthora and Pythium in soils after RSD treatment. Error bars indicate standard deviation. Different lowercase letters show significant differences among the various treatment (SNK tests, $p<0.05$ ). The dashed lines represent the initial value of the original soil.

Real-time PCR results of F. oxysporum were consistent with the plate-count results mentioned above (Figure 5). Applying maize straw at a rate of $5 \mathrm{~g} \mathrm{~kg}^{-1}$ into $100 \%$ WHC or flooded soil could reduce the populations of the pathogen beyond $95 \%$, and over $98 \%$ of pathogens were killed by enhancing the maize straw application rate to $10 \mathrm{~g} \mathrm{~kg}^{-1}$ or 
$20 \mathrm{~g} \mathrm{~kg}^{-1}$. The lowest density of $F$. oxysporum was found in the treatment of flooding coupled with a $20 \mathrm{~g}$ maize straw $\mathrm{kg}^{-1}$ application rate (5.55 log copies $\mathrm{g}^{-1}$ dry soil) while they remained at high levels throughout the experiment (about 7.55 7.82 log copies $\mathrm{g}^{-1}$ dry soil) in CKs and 60\% WHC RSD treatment, as well as in variants with 100\% WHC and flooded soil.

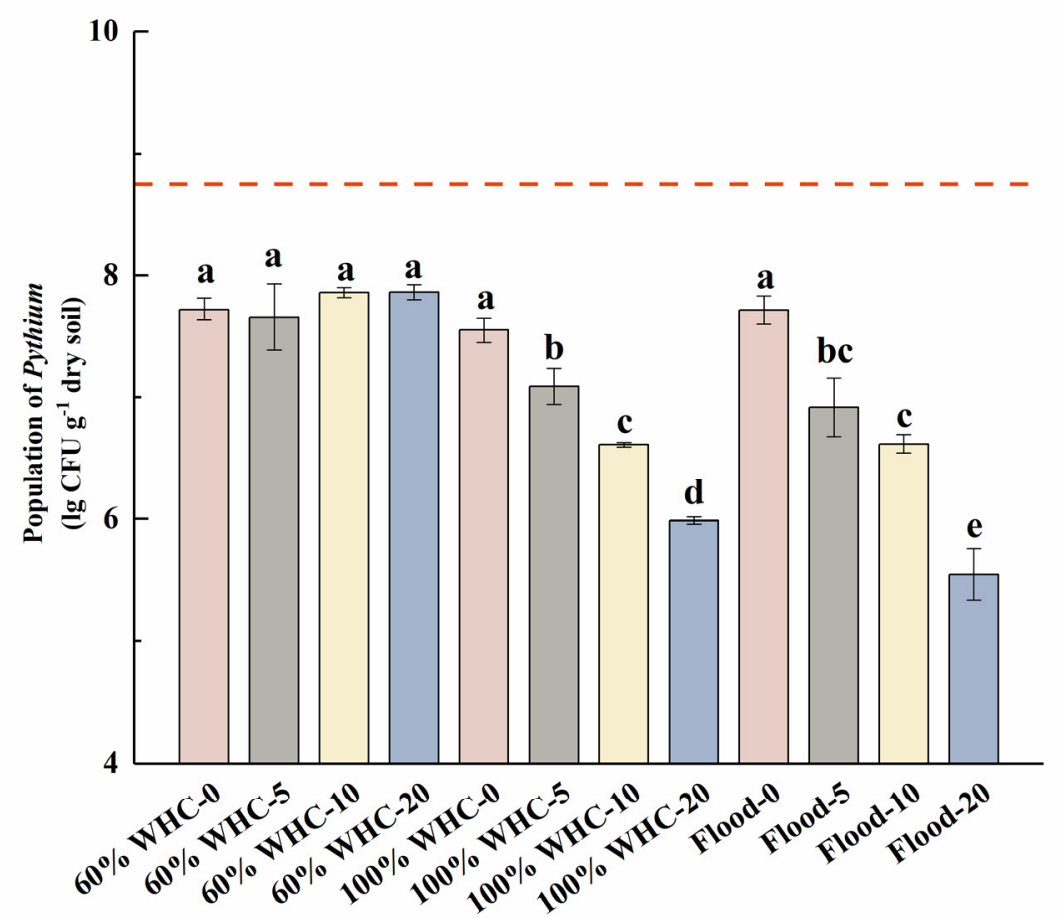

Figure 5. The population of F. oxysporum in soils after RSD treatments through real-time PCR. Error bars indicate standard deviations. Different lowercase letters show significant differences among the various treatments (SNK tests, $p<0.05$ ). The dashed lines represent the initial value of the original soil.

\section{Discussion}

Reductive Soil Disinfestation is a highly efficient and environmentally friendly method of remediating the degraded greenhouse soil over a short period [12]. So far, it has been applied in the field by amending organic material into flooded or water-saturated soil (irrigating soil to $100 \% \mathrm{WHC}$ ), and then mulching plastic film to achieve the desired effect $[9,19,35]$. Maize straw, alfalfa, wheat bran and other easily decomposable agricultural waste could effectively suppress soil-borne pathogens in RSD treatments [23,36,37]. In this study, aiming to promote RSD application in fields where water and straw are difficult and costly to access, we optimized the RSD-treating conditions from different soil water contents (60\% WHC, $100 \%$ WHC and continuous flooding, respectively) and maize straw application rates $\left(0,5,10\right.$, and $20 \mathrm{~g} \mathrm{~kg}^{-1}$, respectively).

Our results showed that all the RSD treatments with different soil water contents and maize straw application rates could effectively remove excessive soil $\mathrm{SO}_{4}{ }^{2-}$ and $\mathrm{NO}_{3}{ }^{-}$, but increase $\mathrm{NH}_{4}{ }^{+}$in degraded soil (Table 3). A relatively low original soil EC could be the reason that RSD treatments did not reduce soil EC significantly. The results showed significant interactions between water content and the maize straw application rate on soil $\mathrm{pH}$ and $\mathrm{NH}_{4}{ }^{+}$(Table 3). Applying a low amount of maize straw $\left(5 \mathrm{~g} \mathrm{~kg}^{-1}\right)$ and irrigating to $60 \%$ WHC significantly reduced soil $\mathrm{SO}_{4}{ }^{2-}$ and $\mathrm{NO}_{3}{ }^{-}$contents and increased $\mathrm{NH}_{4}{ }^{+}$ content, but no further changes in these variables were observed when the maize straw application rate was increased from $5 \mathrm{~g} \mathrm{~kg}^{-1}$ to $20 \mathrm{~g} \mathrm{~kg}^{-1}$ (Figures 1 and 2). As we know, RSD creates a strong anaerobic environment in soil where nitrate can transform into $\mathrm{N}_{2} \mathrm{O}$ or $\mathrm{N}_{2}$ mainly through denitrification, and sulfate can be reduced to $\mathrm{H}_{2} \mathrm{~S}$ or assimilated to 
organic sulfur by soil microbes [10]. Previous research suggested that inputting a large amount of organic matter into anaerobic soil by flooding or irrigating to $100 \%$ WHC could dramatically decrease soil Eh over several days [17]. Here, although $60 \%$ WHC could not fulfill the requirement of completely anaerobic soil, we still found that soil $\mathrm{SO}_{4}{ }^{2-}$ and $\mathrm{NO}_{3}{ }^{-}$experienced a sharp decline after amending maize straw. Moreover, our previous work revealed that increasing the application rate of maize straw might accelerate the speed of Eh decline, but the final Eh were not significantly different [17]. In other words, the low amendment rate of maize straw in $60 \%$ WHC could induce a similar strong reductive environment to reduce nitrate and sulfate contents in the end.

RSD treatment can also remediate severe soil acidification [7]. In this study, soil $\mathrm{pH}$ after RSD treatments was markedly increased and displayed a rising trend with the increasing soil water content (Figure 1). Furthermore, there was a significant interaction between the maize application rate and water content regarding soil $\mathrm{pH}(p<0.05$, Table 2). In $60 \%$ WHC condition, there were no significant differences of soil $\mathrm{pH}$ among the RSD treatments with maize straw application rates of 5, 10 and $20 \mathrm{~g} \mathrm{~kg}^{-1}$, whereas in flooded RSD treatments, soil $\mathrm{pH}$ was increased with the increasing maize straw application rate from $5 \mathrm{~g} \mathrm{~kg}^{-1}$ to $20 \mathrm{~g} \mathrm{~kg}^{-1}$ (Figure 1). Organic amendment decomposition yielded energy and soluble organic carbon, which could promote soil microbe proliferation and accelerate the consumption of soil oxygen simultaneously. Then, the anaerobic soil environment was established. Anaerobic microbes transported electrons to oxidized substances $\left(\mathrm{SO}_{4}{ }^{2-}\right.$, $\left.\mathrm{NO}_{3}{ }^{-}, \mathrm{Fe}^{2+}, \mathrm{Mn}^{2+}\right)$ in soil through anaerobic respiration. The reduction process of these oxidized substances was concomitant with the consumption of $\mathrm{H}^{+}$, which eventually increased soil $\mathrm{pH}$ [38]. The results suggested that if soil $\mathrm{pH}$ needed to be elevated further, a higher soil water content and larger organic material application rate were required for RSD treatment. However, our previous research compared the 100\% WHC and flooded RSD treatments with equal organic material input, and clearly pointed out that their different effects on soil $\mathrm{pH}$ were entirely diminished after 25 days of treatment [17]. The implication was that the RSD treatment with $60 \%$ WHC could achieve the same high pH levels as $100 \%$ WHC or flooded treatment when the incubation time was extended.

RSD needs to apply a large amount of organic materials to soil, where microorganisms are the major agents used to degrade fresh organic matter [39]. Previous studies showed that a huge amount of organic acid was produced by anaerobes in an anaerobic soil environment, especially acetic acid [40], as well as the antagonistic activity of soil microorganisms in the mechanisms of RSD [20]. Our experiment showed the same trend that RSD treatments produced a large amount of organic acid while the proliferation of soil-borne pathogens was suppressed simultaneously after 15 days of incubation. Treatment with organic matter produced acetic acid, propionic acid, butyric acid and isovaleric acid throughout the culture period. Acetic acid was the major organic acid produced by RSD treatment, and was increased with the increasing amended amount of maize straw (from $5 \mathrm{~g} \mathrm{~kg}^{-1}$ soil to $20 \mathrm{~g} \mathrm{~kg}^{-1}$ soil). Continuous flooding treatments with maize straw produced much higher acetic acid and propionic acid in soil solutions than those in $60 \%$

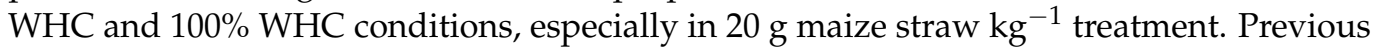
studies showed that organic acids in soil produced during RSD incubation could effectively suppress soil-borne pathogens $[34,41]$. This may be the reason for the better sterilizing effect of flooding coupled with $20 \mathrm{~g}$ maize straw $\mathrm{kg}^{-1}$ soil treatment.

However, unlike RSD treatments of continuous flooding or 100\% WHC, in which more than $90 \%$ soil-borne pathogens were suppressed, only 30 58\% pathogens were inactivated in RSD treatments with 60\% WHC, even lower than that of CK (flooding alone). Applying more maize straw did not increase the mortality of pathogens, but promoted their propagation instead when the water content was set at 60\% WHC (Figure 4). This result is not consistent with existing studies on RSD. A previous study showed that the incorporation of organic matter in soil may be utilized by strains of the saprophytic fungus, which led to a growth in soil pathogen population density [42]. 
All three fungal species tested in this research were mostly saprophytic. This must be why these populations increased at a $60 \%$ WHC condition at high organic amendment rates. Generally, RSD sterilize soil-borne pathogens via three methods: (1) creating a strong reductive and completely anaerobic environment in soil to prevent the aerobe reproduction [7]; (2) producing toxic and volatile fatty acids to inactivate soil-borne pathogens during the process of organic materials anaerobic fermentation [43]; (3) inducing compositional shifts of microbes by diverse Clostridium sp. becoming the dominant species and improving soil biodiversity [44]; (4) inducing proliferation and dynamic compositional changes in the Firmicutes community, including methyl sulfide compounds, through a metabolic method [45]. The three ways work together to achieve the suppression of soil-borne pathogens in soil [9]. At $60 \%$ WHC amended with maize straw, the anaerobic environment was less sufficient than that in $100 \%$ WHC or flooded soil. What is more, organic acids contents were kept at very low levels during the whole RSD treatment period and were not dependent on maize straw application rates from $5 \mathrm{~g} \mathrm{~kg}^{-1}$ to $20 \mathrm{~g} \mathrm{~kg}^{-1}$ (Figure 3). This could be one of the most important reasons why RSD treatment with soil water content of $60 \%$ WHC could not effectively inactivate soil-borne pathogens. Conversely, when soil water content was set at $60 \%$ WHC for RSD treatment, the populations of soil-borne pathogens were even increased when the maize straw application reached $20 \mathrm{~g} \mathrm{~kg}^{-1}$ (Figure 4). This result implied that the trapped soil air at a soil water content of $60 \%$ WHC could temporarily support soil-borne pathogens, as aerobes [44], to grow and reproduce, provided that they were rich in carbon and nitrogen [34].

\section{Conclusions}

RSD is an economic and effective method to restore degraded greenhouse soil. Although applying maize straw into $60 \%$ WHC soil is adequate to alleviate soil acidification and salinization, we found that it could not effectively inactivate soil-borne pathogens. Developing a complete anaerobic soil condition by irrigating soil to at least $100 \%$ WHC is necessary in order to suppress soil-borne pathogens; therefore, 100\% WHC must be held and $10 \mathrm{~g} \mathrm{~kg}^{-1}$ of maize straw must be applied (18 Mg per ha per $15 \mathrm{~cm}$ depth in the field).

Soil was recommended for the RSD field operation to both improve soil properties and suppress soil-borne pathogens.

Author Contributions: Conceptualization, Z.C. and J.Z.; methodology, Z.C., T.W. and R.Z.; software, R.Z.; validation, T.W.; formal analysis, R.Z.; resources, Z.C, X.H. and T.W.; data curation, T.W., X.H. and X.L.; writing-original draft preparation, R.Z.; writing-review and editing, T.W. and R.Z.; visualiza-tion, R.Z.; supervision, T.W. and X.H.; project administration, Z.C. and X.H.; funding acquisition, Z.C. and X.H. All authors have read and agreed to the published version of the manuscript.

Funding: This work was financially supported by the Key-Area Research and Development Program of Guangdong Province (2020B0202010006), the National Natural Science Foundation of China (42090065), and the Priority Academic Program Development (PAPD) of Jiangsu Higher Education Institutions.

Institutional Review Board Statement: Not applicable.

Informed Consent Statement: Not applicable.

Conflicts of Interest: The authors declare no conflict of interest.

\section{References}

1. Lal, R. Soil management in the developing countries. Soil Sci. 2000, 165, 57-72. [CrossRef]

2. Ju, X.; Kou, C.; Zhang, F.; Christie, P. Nitrogen balance and groundwater nitrate contamination: Comparison among three intensive cropping systems on the North China Plain. Environ. Pollut. 2006, 143, 117-125. [CrossRef] [PubMed]

3. Shi, W.M.; Yao, J.; Yan, F. Vegetable cultivation under greenhouse conditions leads to rapid accumulation of nutrients, acidification and salinity of soils and groundwater contamination in South-Eastern China. Nutr. Cycl. Agroecosyst. 2009, 83, 73-84. [CrossRef]

4. Zhou, D.P.; Chu, C.B.; Liu, F.F.; Fan, J.Q.; Jiang, Z.F.; Wu, S.H. Effect of asparagu's cultivation years on physio-chemical properties, microbial community and enzyme activities in greenhouse soil. Plant Nutr. Fert. Sci. 2012, 2, 459-466. 
5. Li, J.; Pu, L.; Han, M.; Zhu, M.; Zhang, R.; Xiang, Y. Soil salinization research in China: Advances and prospects. J. Geogr. Sci. 2014, 24, 943-960. [CrossRef]

6. Singh, A. Soil salinization management for sustainable development: A review. J. Environ. Manag. 2021, 277, 111383. [CrossRef] [PubMed]

7. Momma, N.; Kobara, Y.; Uematsu, S.; Kita, N.; Shinmura, A. Development of biological soil disinfestations in Japan. Appl. Microbiol. Biotechnol. 2013, 97, 3801-3809. [CrossRef]

8. Shinmura, A.; Sakamoto, N.; Abe, H. Control of Fusarium root rot of Welsh onion by soil reduction. Jpn. J. Phytopathol 1999, 65, 352-353.

9. Blok, W.J.; Lamers, J.G.; Termorshuizen, A.J.; Bollen, G.J. Control of soilborne plant pathogens by incorporating fresh organic amendments followed by tarping. Phytopathology 2000, 90, 253-259. [CrossRef] [PubMed]

10. Zhu, T.; Dang, Q.; Zhang, J.; Müller, C.; Cai, Z. Reductive soil disinfestation (RSD) alters gross N transformation rates and reduces $\mathrm{NO}$ and $\mathrm{N}_{2} \mathrm{O}$ emissions in degraded vegetable soils. Plant Soil 2014, 382, 269-280. [CrossRef]

11. Wen, T.; Huang, X.; Zhang, J.; Zhu, T.; Meng, L.; Cai, Z. Effects of water regime, crop residues, and application rates on control of Fusarium oxysporum f. sp. cubense. J. Environ. Sci. 2015, 31, 30-37. [CrossRef] [PubMed]

12. Goud, J.K.C.; Termorshuizen, A.J.; Blok, W.J.; Van Bruggen, A.H. Long-term effect of biological soil disinfestation on Verticillium wilt. Plant Dis. 2004, 88, 688-694. [CrossRef] [PubMed]

13. Butler, D.M.; Rosskopf, E.N.; Kokalis-Burelle, N.; Albano, J.P.; Muramoto, J.; Shennan, C. Exploring warm-season cover crops as carbon sources for anaerobic soil disinfestation (ASD). Plant Soil 2012, 355, 149-165. [CrossRef]

14. Kobara, Y.; Uematsu, S.; Tanaka-Miwa, C.; Sato, R.; Sato, M. Possibility of the new soil fumigation technique with ethanol solution. In Proceedings of the 2007 Annual Research Conference on Methyl Bromide Alternatives and Emissions Reduction, San Diego, CA, USA, 29 October-1 November 2007; p. 74.

15. Momma, N.; Usami, T.; Amemiya, Y.; Shishido, M. Factors involved in the suppression of Fusarium oxysporum f. sp. lycopersici by soil reduction. Soil Microorg. (Jpn.) 2005, 59, 27-33.

16. Shinmura, A. Principle and effect of soil sterilization method by reducing redox potential of soil. PSJ Soilborne Dis. Workshop Rep. 2004, 22, 2-12.

17. Wen, T.; Huang, X.; Zhang, J.; Cai, Z. Effects of biological soil disinfestation and water regime on suppressing Artemisia selengensis root rot pathogens. J. Soils Sediments 2016, 16, 215-225. [CrossRef]

18. Snyder, G.H. Agricultural flooding of organic soils. In Bulletin/University of Florida. Agricultural Experiment Station (USA); University of Florida, Agricultural Experiment Stations: Gainesville, FL, USA, 1987.

19. Momma, N.; Momma, M.; Kobara, Y. Biological soil disinfestation using ethanol: Effect on Fusarium oxysporum f. sp. lycopersici and soil microorganisms. J. Gen. Plant Pathol. 2010, 76, 336-344. [CrossRef]

20. Kubo, C. Analysis of factors involved in sterilization effect by soil reduction. Jpn. J. Phytopathol. 2005, 71, 281-282. [CrossRef]

21. Matsuoka, K.; Moritsuka, N.; Kusaba, S.; Hiraoka, K. Concentrations of natural stable Cs in organs of blueberry bushes grown in three types of soils treated with acidification or fertilization. Hortic. J. 2019, 88, 31-40. [CrossRef]

22. Matsuoka, K.; Moritsuka, N.; Kusaba, S.; Hiraoka, K. Effects of soil type and soil treatment on solubilization of 13 elements in the root zone and their absorption by blueberry bushes. Hortic. J. 2018, 87, 155-165. [CrossRef]

23. Meng, T.; Yang, Y.; Cai, Z.; Ma, Y. The control of Fusarium oxysporum in soil treated with organic material under anaerobic condition is affected by liming and sulfate content. Biol. Fertil. Soils 2018, 54, 295-307. [CrossRef]

24. Lu, R.K. Soil and Agro-Chemistry Analysis Methods; China Agricultural Science and Technology Press: Beijing, China, 2000.

25. Meng, T.; Zhu, T.; Zhang, J.; Cai, Z. Effect of liming on sulfate transformation and sulfur gas emissions in degraded vegetable soil treated by reductive soil disinfestation. J. Environ. Sci. 2015, 36, 112-120. [CrossRef]

26. Schumacher, B.A. Methods for the determination of total organic carbon (TOC) in soils and sediments. US Environ Prot Agency. 2002, 32, 25.

27. Bremner, J. Determination of nitrogen in soil by the Kjeldahl method. J. Agric. Sci. 1960, 55, 11-33. [CrossRef]

28. Blair, G.J.; Lefroy, R.D.B.; Lise, L. Soil carbon fractions based on their degree of oxidation, and the development of a carbon management index for agriculture systems. Aust. J. Agric. Res. 1995, 46, 1459-1466. [CrossRef]

29. Ling, N.; Huang, Q.; Guo, S.; Shen, Q. Paenibacillus polymyxa SQR-21 systemically affects root exudates of watermelon to decrease the conidial germination of Fusarium oxysporum $f$. sp. niveum. Plant Soil 2011, 341, 485-493. [CrossRef]

30. Sun, E.; Su, H.; Ko, W. Identification of Fusarium oxysporum $f$. sp. cubense race 4 from soil or host tissue by cultural characters [Bananas, wilt]. Phytopathology (USA) 1978, 68, 1672-1673.

31. Dineen, S.M.; Aranda, R.; Anders, D.L.; Robertson, J.M. An evaluation of commercial DNA extraction kits for the isolation of bacterial spore DNA from soil. J. Appl. Microbiol. 2010, 109, 1886-1896. [CrossRef] [PubMed]

32. Gardes, M.; Bruns, T.D. ITS primers with enhanced specificity for basidiomycetes-application to the identification of mycorrhizae and rusts. Mol. Ecol. 1993, 2, 113-118. [CrossRef]

33. Lievens, B.; Brouwer, M.; Vanachter, A.C.; Lévesque, C.A.; Cammue, B.; Thomma, B.P. Quantitative assessment of phytopathogenic fungi in various substrates using a DNA macroarray. Environ. Microbiol. 2005, 7, 1698-1710. [CrossRef] [PubMed]

34. Huang, X.; Wen, T.; Zhang, J.; Meng, L.; Zhu, T.; Cai, Z. Toxic organic acids produced in biological soil disinfestation mainly caused the suppression of Fusarium oxysporum $f$. sp. cubense. BioControl 2015, 60, 113-124. [CrossRef] 
35. Muramoto, J.; Shennan, C.; Fitzgerald, A.; Koike, S.; Bolda, M.; Daugovish, O.; Rosskopf, E.; Kokalis-Burelle, N.; Butler, D. Effect of anaerobic soil disinfestation on weed seed germination. In Proceedings of the Annual International Research conference on Methyl Bromide Alternatives and Emissions Reductions, Orlando, FL, USA, 11-14 November 2008; Available online: https: / / mbao.org/prev_year (accessed on 25 October 2021).

36. Huang, X.; Liu, L.; Wen, T.; Zhu, R.; Zhang, J.; Cai, Z. Illumina MiSeq investigations on the changes of microbial community in the Fusarium oxysporum f. sp. cubense infected soil during and after reductive soil disinfestation. Microbiol. Res. 2015, 181, 33-42. [CrossRef] [PubMed]

37. Momma, N. Biological soil disinfestation (BSD) of soilborne pathogens and its possible mechanisms. JARQ 2008, 42, 7-12. [CrossRef]

38. Ponnamperuma, F.N. The chemistry of submerged soils. In The Chemistry of Submerged Soils; Academic Press: Cambridge, MA, USA, 1972; Volume 24, pp. 29-96.

39. Chandrasekaran, S.; Yoshida, T. Effect of organic acid transformations in submerged soils on growth of the rice plant. Soil Sci. Plant Nutr. 1973, 19, 39-45. [CrossRef]

40. Na, P.; Kairong, W.; Buresh, R. Effect of rice straw incorporation on concentration of organic acids and available phosphorus in soil under different water regimes. Acta Pedol. Sin. 2006, 43, 347.

41. Simmons, C.W.; Higgins, B.; Staley, S.; Joh, L.D.; Simmons, B.A.; Singer, S.W.; Stapleton, J.J.; VanderGheynst, J.S. The role of organic matter amendment level on soil heating, organic acid accumulation, and development of bacterial communities in solarized soil. Appl. Soil Ecol. 2016, 106, 37-46. [CrossRef]

42. Henry, P.M.; Haugland, M.; Lopez, L.; Munji, M.; Watson, D.C.; Gordon, T.R. The potential for Fusarium oxysporum f. sp. fragariae, cause of fusarium wilt of strawberry, to colonize organic matter in soil and persist through anaerobic soil disinfestation. Plant Pathol. 2020, 69, 1218-1226. [CrossRef]

43. Momma, N.; Yamamoto, K.; Simandi, P.; Shishido, M. Role of organic acids in the mechanisms of biological soil disinfestation (BSD). J. Gen. Plant Pathol 2006, 72, 247-252. [CrossRef]

44. Mowlick, S.; Hirota, K.; Takehara, T.; Kaku, N.; Ueki, K.; Ueki, A. Development of anaerobic bacterial community consisted of diverse clostridial species during biological soil disinfestation amended with plant biomass. Soil Sci. Plant Nutr. 2012, 58, 273-287. [CrossRef]

45. Hewavitharana, S.S.; Klarer, E.; Reed, A.J.; Leisso, R.; Poirier, B.; Honaas, L.; Rudell, D.R.; Mazzola, M. Temporal dynamics of the soil metabolome and microbiome during simulated anaerobic soil disinfestation. Front. Microbiol. 2019, 10, 2365. [CrossRef] 